\title{
FENOMENOLOGI APLIKASI TIKTOK BAGI USAHA ONLINE MARICA FARMS
}

\author{
Asia Khairunnisa Luthan ${ }^{1 *}$, Zahira Xenia Asmoro Putri ${ }^{1}$ \\ ${ }^{1}$ Program Studi Ilmu Komunikasi FISIP Universitas Al Azhar Indonesia, Jakarta Selatan \\ *Email: luthanasiah@gmail.com
}

\begin{abstract}
The TikTok phenomenon has become a widespread phenomenon throughout the world. The TikTok application is now a trend as well as evidence of technological developments that help humans carry out their activities. Not only as a medium for self-existence but also used by online business actors, one of which is Marica Farms. This study aims to describe the phenomenology of the TikTok application for Marica Farms' online business. Marica Farms is an online animal sacrifice business that uses the TikTok application to help market its products. Using a phenomenological approach, the researcher finds out the meaning of the TikTok application for Marica Farms' online business. Equipped with Uses and Gratification Theory which helps researchers in analyzing the phenomenon of the TikTok application for Marica Farms online business. Data were collected using in-depth interviews with the owners of Marica Farms. The results of this study are the phenomenology of the TikTok application for Marica Farms' online business, namely as a medium that makes it easier for online businesses to have things out of the box, reach a broad market and help increase knowledge and awareness of Marica Farms' online business. The content provided by TikTok Marica Farms has also been adapted to the needs of its audience, such as information and entertainment needs so that the audience feels satisfied.
\end{abstract}

Keywords: Phenomenology; TikTok; Marica Farms; Uses and Gratifications Theory

\begin{abstract}
ABSTRAK
Fenomena TikTok sudah menjadi hal yang merebak berbagai kalangan di seluruh dunia. Aplikasi TikTok sekarang ini menjadi sebuah trend sekaligus bukti adanya perkembangan teknologi yang membantu manusia dalam menjalankan aktivitasnya. Bukan hanya sebagai media untuk ajang eksistensi diri, namun juga digunakan oleh para pelaku usaha online salah satunya Marica Farms. Penelitian ini bertujuan untuk mendeskripsikan fenomenologi aplikasi TikTok bagi usaha online Marica Farms. Marica Farms yaitu usaha online hewan kurban yang menggunakan aplikasi TikTok untuk membantu memasarkan produknya. Dengan pendekatan fenomenologi, peneliti mencari tahu makna aplikasi TikTok bagi usaha online Marica Farms. Dilengkapi dengan Teori Uses and Gratification yang membantu peneliti dalam menganalisis fenomena aplikasi TikTok bagi usaha online Marica Farms. Pengumpulan data dilakukan dengan wawancara mendalam dengan pemilik Marica Farms. Hasil penelitian ini yaitu Fenomenologi aplikasi TikTok bagi usaha online Marica Farms yaitu sebagai media yang mempermudah usaha online jadi memiliki hal yang out of the box, menjangkau pasar yang luas dan membantu dalam meningkatkan pengetahuan serta awareness pada usaha online Marica Farms. Konten-konten yang disediakan TikTok Marica Farms juga sudah disesuaikan dengan kebutuhan khalayaknya seperti kebutuhan informasi dan hiburan agar khalayak merasa puas.

Kata Kunci: Fenomenologi; TikTok; Marica Farms; Teori Uses and Gratifications Submisi: 18 Juli 2021
\end{abstract}




\section{Pendahuluan}

Perkembangan teknologi sekarang semakin maju, berbagai media elektronik dan cetak berlomba-lomba memperbaharui wajah dalam memenuhi kebutuhan komunikasi setiap individu. Segala kebutuhan manusia saat ini sudah berbasis pada digital atau internet, mulai dari kebutuhan informasi, hiburan, bahkan kebutuhan untuk mencari keuntungan. Kelebihan dari media digital atau internet memang di ciptakan untuk mempermudah pekerjaan manusia. Banyak hal yang dapat dilakukan oleh masyakat dalam menggunakan internet, seperti berinteraksi, berbagi informasi, mengekspresikan diri, menunjukan identitas dirinya berasal dari kalangan mana atau bahkan mencari penghasilan tambahan. Internet juga menjadi salah satu sumber informasi tentang hal-hal apapun, apa yang ingin kita cari dan butuhkan, pasti ada didalamnya.

Wadah untuk segala kegiatankegiatan tersebut dapat kita lakukan melalui media sosial. Media sosial adalah salah satu komunikasi baru yang saaat ini ramai di perbincangkan dan termasuk ke dalam media yang sering di akses atau digunakan oleh setiap orang, hampir dimana pun dan kapan pun mereka berada setiap orang menggunakan media sosial dengan sesuai kebutuhan mereka sendiri. Banyak sekali media sosial yang dapat kita temukan di dunia ini, dikutip dari portal berita online CNN Indonesia, Sensor Tower merilis lima media sosial populer atau sering digunakan di dunia sepanjang kuartal II tahum 2020, diantaranya yaitu TikTok, Facebook, Instagram, Snapchat, dan Likee (Ikhsan 2020)

Pada Februari 2021, Sensor Tower melakukan penelitian Kembali mengenai media sosial terpopuler di dunia yang hasilnya diungguli oleh TikTok dengan jumlah unduhan lebih dari 56 juta kali. Memang sekarang ini masyarakat sangat banyak yang gemar menggunakan aplikasi TikTok. Dilengkapi dengan fitur-fitur menarik seperti musik, voice changer, sticker, effect, filter, beautify, hingga timer, membuat masyarakat memanfaatkan TikTok untuk kegiatan sehari-harinya. Selain itu hal yang paling diingat banyak orang ketika mendengar aplikasi TikTok yaitu FYP yang merupakan singkatan dari For Your Page. Istilah ini berkaitan dengan kolom "For You" di beranda atau halaman depan aplikasi TikTok. Ketika membuka aplikasi TikTok, pengguna dapat menemukan banyak video rekomendasi. Apabila pengguna juga membuat konten video, belum tentu video tersebut bisa masuk di FYP. Video yang dapat masuk dalam FYP adalah video-video dengan jumlah like dan viewers yang sangat banyak atau video yang sedang trending.

Kepopuleran TikTok karena fiturfitur yang ditawarkan tidak kalah menarik dengan media sosial lainnya, hal itu membuat Indonesia sebagai salah satu negara dengan pengguna TikTok terbesar di Indonesia. Berdasarkan laporan yang diproduksi oleh Statista bahwa per Februari 2021 diperkirakan pengguna aktif TikTok secara global mencapai 35,28 juta pengguna. Laporan tersebut juga menyebutkan bahwa pengguna TikTok didominasi oleh kalangan muda atau Generasi dengan kisaran usia 1824 tahun. Riset juga mengatakan bahwa pengguna TikTok menghabiskan waktu sekitar 89 menit sehari. Beberapa orang juga menyebutkan bahwa TikTok dapat mempengaruhi seseorang dalam menciptakan minat beli yang sebelumnya tidak pernah terencanakan setelah melihat konten-konten yang terdapat di TikTok (Stephanie 2020)

Fenomena TikTok saat ini tengah ramai di kalangan masyarakat sebagai ajang untuk menampilkan eksistensi dan mencari atau mendapatkan informasi, saat ini aplikasi TikTok tidak hanya sebagai platform hiburan semata, namun aplikasi TikTok membawa sebuah fenomena baru bagi para pengusaha untuk mendapatkan keuntungan dan melakukan kebutuhannya dalam menjual barang maupun jasa lalu memasarkannya melalui aplikasi TikTok, teknik pemasaran yang dilakukan pun beraneka macam dan kreatif dengan 
membuat konten-konten yang dapat mengundang daya tarik masyarakat yang melihatnya. Para pengusaha yang menggunakan aplikasi TikTok sebagai media untuk berjualan berlomba-lomba untuk menciptakan konten yang menarik agar dapat trending di FYP, sehingga masyarakat yang melihat dapat langsung tertuju pada usaha tersebut.

Fenomena aplikasi TikTok dapat dimaknai dalam sebuah pendekatan fenomenologi. Fenomenologi mempelajari bagaimana sebuah fenomena dialami secara sadar dalam pikiran maupun tindakan, seperti bagaimana fenomena tersebut bernilai atau dapat diterima secara etis, karena fenomena itu sendiri tiada lain adalah fakta yang disadari dan masuk kedalam pemahaman manusia. Seiring dengan tujuan penggunaan fenomenologi yaitu memahami makna sesuatu berdasarkan pengalaman dan pengertian sehari-hari (Subadi 2006:12), dengan begitu dalam penelitian ini akan membahas bagaimana suatu individu memaknai fenomena aplikasi TikTok sebagai medium untuk memenuhi kebutuhan dalam melakukan pemasaran. Objek penelitian dari penelitian ini yaitu seorang pelaku usaha online yang menggunakan aplikasi TikTok tentunya secara sadar memiliki motif dan tindakan tertentu.

Salah satu usaha online yang menggunakan aplikasi TikTok serta menjadi informan pada penelitian ini yaitu Marica Farms. Per tanggal 27 Juli 2021 Marica Farms sudah memiliki 23.600 jumlah followers yang mengikuti akun TikTok nya. Marica Farms memiliki keunikan tersendiri karena penjual hewan kurban yang biasanya kita lihat menjajakan jualannya dipinggir jalan, namun saat ini penjual hewan kurban pun juga beralih menggunakan media sosial. Marica Farms memasarkan hewan-hewan kurbannya tersebut melalui sebuah video TikTok yang dikemas secara menarik hingga mencuri banyak perhatian masyarakat karena hampir semua video TikTok nya berhasil FYP atau masuk ke laman beranda masyarakat karena mendapat likes hingga 434.800 likes serta banyaknya viewers dari konten-konten yang mereka buat. Dengan begitu, para pelaku usaha online dituntut memiliki kreativitas dalam menciptakan konten-konten yang dapat menarik pelanggan agar tujuan pemasaran dapat tercapai.

Secara khusus, penelitian ini akan membahas mengenai apa saja alasan-alasan para pelaku usaha online menggunakan aplikasi TikTok yang tengah ramai digunakan oleh masyarakat untuk memenuhi kebutuhan dalam melakukan kegiatan pemasaran.

\section{Fenomenologi}

Fenomenologi dicetuskan secara intens sebagai kajian filsafat pertama kali oleh Edmund Husserl (1859-1938), sehingga Husserl sering dipandang sebagai Bapak Fenomenologi. Filsafatnya sangat popular sekitar tahun 1950-an. Tujuan utama filsafat ini adalah memberi landasan bagi filsafat agar dapat berfungsi sebagai ilmu yang murni dan otonom (Kuper, Kuper, and Munandar 2000:749). Kemunculan fenomenologi oleh Husserl dilatarbelakangi oleh kenyataan terjadinya krisis ilmu pengetahuan. Dalam krisis ini, ilmu pengetahuan tidak bisa memberikan nasihat apa-apa bagi manusia. Ilmu pengetahuan senjang dari praktik hidup sehari-hari. Hal ini, menurut Husserl, konsep teori sejati telah banyak dilupakan oleh banyak disiplin yang maju dalam kebudayaan ilmiah dewasa ini. Sehubungan dengan itu, Husserl menagjukan kritik terhadap ilmu pengetahuan sebagai berikut (Hasbiansyah 2008):

1) Ilmu pengetahuan telah jatuh pada objektivisme, yaitu cara memandang dunia sebagai susunan fakta objektif dengan kaitan-kaitan niscaya. Bagi Husserl, pengetahuan seperti itu berasal dari pengetahuan prailmiah sehari-hari, yang disebut lebenswelt.

2) Kesadaran manusia atau subjek ditelah oleh tafsiran-tafsiran objektivis itu, karena ilmu pengetahuan sama sekali tidak 
membersihkan diri dari kepentingankepentingan dunia kehidupan seharihari itu.

3) Teori yang dihasilkan dari usaha membersihkan pengetahuan dari kepentingan-kepentingan itu adalah teori sejati yang dipahami tradisi pemikiran Barat.

Dengan kata lain, fenomenologi Husserl ini berangkat dari filsafat ilmu. Dalam hal ini, ia mengusulkan bahwa fenomena-fenomena itu untuk dipahami, harus didekati dengan cara-cara yang khas. Selain itu, fenomenologi berfokus pada pengalaman personal, termasuk bagaimana para individu mengalami satu sama lain (Littlejohn 2002:13). Oleh karena itu, komunikasi dipandang sebagai hubungan interpersonal melalui dialog yang dilakukan secara bersamaan.

Didalam Fenomenologi memiliki upaya untuk mengungkapkan tentang suatu makna dari pengalaman seseorang. Menurut Littlejohn dan Foss, fenomenologi berkaitan dengan penampakan suatu objek, peristiwa, atau suatu kondisi dalam persepsi kita. Pengetahuan berasal dari pengalaman yang didasari, dalam persepsi kita (Littlejohn and Foss 2005:38). Dalam hal ini, fenomenologi berarti datangnya suatu makna yang berinteraksi dengan subjek dan hal tersebut akan terbentuk suatu fenomena.

\section{Aplikasi TikTok}

TikTok merupakan aplikasi yang diciptakan oleh perusahaan teknologi milik negara Republik Rakyat Tiongkok (RRT) yang selanjutnya dipasarkan kepada masyarakat pada tahun 2017. Aplikasi ini digunakan untuk membuat serta membagikan video pendek berdurasi 15-60 detik. Aplikasi ini menyediakan tempat untuk menyunting video dengan fitur-fitur seperti latar belakang musik, penambahan teks ataupun stiker serta menyediakan special effect. Kemudahan, kecanggihan, dan simplisitas yang ditawarkan tersebut memberikan akses kepada seluruh penggunanya untuk menjadi content creator hanya dengan menggunakan satu aplikasi (Massie 2020)

Spesifikasi target pasar yang sudah ditetapkan dari awal merupakan salah satu penyebab ByteDance mengembangkan aplikasi tersebut seperti itu. Target tersebut ialah remaja berusia dibawah 18 tahun. Oleh karena itu, pada tahun 2018, TikTok mengambil alih aplikasi Musical.ly yang saat itu mendominasi pasar remaja AS (Amerika Serikat). Namun, seiring dengan berjalannya waktu TikTok berhasil menembus targetnya dan digunakan bukan hanya oleh remaja berumur dibawah 18 tahun. Berdasarkan data per tahun 2019, $41 \%$ pengguna aplikasi ini berumur 16-24 tahun. Tidak hanya itu, aplikasi ini juga digunakan oleh usia yang lebih tua meskipun dengan persentase yang lebih kecil. Selain itu, aplikasi ini terus mengembangkan roketnya hingga tersedia di 155 negara dengan data user aktif (per 22 Mei 2020) mencapai 800 juta pengguna aktif di seluruh dunia. Aplikasi ini juga menempati posisi ke-4 pada the most downloaded apps pada tahun 2019 mengalahkan Instagram yang berada di posisi ke-5 (Mohsin 2021).

Indonesia menjadi salah satu negara yang aktif dalam menggunakan aplikasi TikTok. Sebagaimana laporan dari Sensor Tower, Indonesia menjadi salah satu negara penyumbang pengguna aktif TikTok dengan jumlah 11 persen. Setelah Indonesia, Brazil juga menjadi negara terbanyak penyumbang pengguna aktif TikTok dengan jumlah 9 persen (Pertiwi 2020).

Adapun tujuan seseorang menggunakan aplikasi berdasarkan pernyataan menurut Omar \& Dequan yaitu, Pertama, ingin berinteraksi. Interaksi sosial melalui TikTok didukung dengan beberapa fitur seperti follow, comment, like, share, upload dan duet. Duet merupakan fitur yang tidak ada di sebagian besar media sosial. Kedua, archiving atau menyimpan memori. Berdasarkan penelitian Omar \& Deequan, hal ini yang paling menonjol dalam motivasi seseorang dalam menggunakan TikTok. Hal ini didukung dengan fitur save video atau 
"menyimpan video" yang kembali lagi, menjadi keunggulan TikTok. Ketiga, selfexpression atau pengekspresian diri. Melalui TikTok seseorang dapat mengekspresikan dirinya secara kreatif melalui video-video yang dibuat (Omar and Dequan 2020).

Maraknya fenomena TikTok ditengah masyarakat dan banyaknya hal yang ditawarkan oleh TikTok membuat seluruh masyarakat menggunakan aplikasi ini menjadi wadah untuk berkreatifitas, mengekspresikan diri, mencari informasi, bahkan dimanfaatkan oleh masyarakat sebagai tempat melakukan kegiatan pemasaran. Sehingga kehadiran TikTok ini dapat dimanfaatkan oleh masyarakat untuk melakukan seluruh kegiatan dengan cakupan yang luas dan waktu yang cepat.

\section{Teori Uses and Gratifications}

Teori Uses and Gratifications (U\&G) adalah teori yang berangkat dari kajian komunikasi massa. U\&G memandang khalayak sebagai individu yang memiliki kemampuan memilih isi media berdasarkan kebutuhannya. Teori U\&G berfokus pada motif dan kepuasan individu saat menggunakan media dan tidak fokus pada efek media (Kriyantono 2014:335). Philip Palmgreen, profesor komunikasi Kentucky University mengembangkan teori U\&G dengan menanyakan apakah motif khalayak dapat dipenuhi oleh media atau apakah khalayak puas setelah menggunakan media tersebut (Kriyantono 2014:338). Secara sederhanya khalayak memilih suatu program sesuai dengan kebutuhannya atau keinginannya. Model U\&G menunjukkan bahwa yang menjadi permasalahan utama bukanlah bagaimana media mengubah sikap dan perilaku masyarakat, tetapi bagaimana memenuhi kebutuhan pribadi dan sosial masyarakat. Jadi, bobotnya ialah pada khlayak yang aktif, yang sengaja menggunakan media untuk mencapai tujuan khusus (Effendy 2003:290). Dalam menjalankan proses komunikasi harus berangkat dari prinsip know your audience. Baik dari jenis isi pesan maupun cara mendiseminasi pesan, proses komunikasi mesti berangkat dari pertanyaan: "Siapa khalayaknya? Bagaimana karakteristik khalayaknya? Apa yang dibutuhkan khalayak? Apakah pesan yang dibuat sesuai dengan kebutuhan khalayak? Apakah cara menyampaikan pesannya sesuai dengan karakteristik khalayaknya?" (Effendy 2003:339).

Teori U\&G melihat pada motifmotif atau kebutuhan suatu individu dalam menggunakan medium, yang dimana motif tiap individu pun berbeda-beda dalam menggunakan medium tersebut Oleh karena itu, sudut pandang pada penelitian ini untuk mengetahui apa alasan memilih medium tersebut disaat banyak medium lain dan apa saja yang didapat ketika individu tersebut menggunakan medium tersebut.

\section{Metode Penelitian}

Metode yang digunakan dalam penelitian ini yaitu kualitatif dengan pendekatan fenomenologi. Pendekatan fenomenologi bertujuan untuk memahami makna dari suatu peristiwa dan pengaruhnya pada pelaku. Sifat pada penelitian ini yaitu deskriptif yang bermaksud pada penyusunan penelitian secara sistematis, faktual, dan akurat.

Objek yang difokuskan pada penelitian ini yaitu pelaku usaha online yang menggunakan aplikasi TikTok sebagai medium pemasaran untuk memenuhi kebutuhan dalam melakukan kegiatan pemasaran produknya. Dalam hal ini peneliti ingin mengetahui apa saja alasan ia menggunakan aplikasi TikTok sebagai tempat pemasaran, mengetahui makna penggunaan aplikasi TikTok bagi pelaku usaha online dengan kebutuhan audiens, dan mengetahui kepuasan audiens akan konten TikTok tersebut.

Langkah-langkah analisa data akan melalui tahap (Usman and Akbar 2006:66) sebagai berikut yang pertama pengumpulan data, baik data hasil observasi (pengamatan) maupun data dari hasil wawancara mendalam, Kedua reduksi data yakni memilih hal-hal pokok dari data yang telah terkumpul yang sesuai dengan 
masalah penelitian ini. Reduksi data berlangsung secara terus menerus selama proses penelitian berlangsung, ketiga display data yakni menyajikan data dalam bentuk narasi, matrik, network, chart, grafik, tabel, gambar, dan sebagainya dan yang keempat pengambilan keputusan dan verifikasi. Hasil kesimpulan dan verifikasi ini akan diarahkan pada pemaparan saran dan rekomendasi.

Adapun teknik analisa data dalam penelitian ini akan melalui pengumpulan hasil data berupa wawancara mendalam dengan objek penelitian. Kemudian akan melalui tahap coding yaitu open coding, axial coding, dan selective coding, hasil coding akan disajikan dalam bentuk narasi.

\section{Hasil Dan Pembahasan}

Setelah melakukan wawancara mendalam dengan pemilik usaha online Marica Farms, peneliti mendapatkan beberapa jawaban dari pertanyaan yang diajukan mengenai alasan-alasan mereka menggunakan aplikasi TikTok disaat banyak media sosial yang dapat dimanfaatkan.

\section{Alasan penggunaan aplikasi TikTok}

Pemilik usaha Marica Farms memberikan pernyataan mengenai alasan mereka menggunakan aplikasi TikTok sebagai medium untuk menggunakan kebutuhan bisnisnya, hal tersebut dapat kita lihat pada kutipan wawancara sbb:

"Branding TikTok bisa bawa audiens ke market place di Shopee dan Tokopedia"

"TikTok paling powerful dibanding media lainnya"

"TikTok, kita ga butuh followers banyak dulu, cukup kita tau strategi dan marketingnya gimana untuk video kita dapet jangkauan banyak orang"

"Bisa ngebawa video kita dan orang orang TikTok ke Instagram kita"

"Selain itu TikTok juga punya fitur lagu yang lagu lagunya banyak yang viral jadi orang lebih interest untuk nonton sampe akhir"

Usaha online Marica Farms menggunakan aplikasi TikTok karena TikTok dapat membawa audiens ke akun Instagram juga ke marketplace seperti Shopee dan Tokopedia. TikTok dianggap paling powerful dibanding media lain. Dengan TikTok tidak perlu menunggu banyak followers, ketika sudah tau strategi marketingnya bisa mendapat jangkauan pasar yang luas. Fitur lagu juga membuat khalayak di TikTok lebih tertarik untuk menonton konten hingga akhir.

\section{Makna penggunaan aplikasi TikTok bagi usaha online Marica Farms}

Pemilik usaha Marica Farms mengungkapkan makna penggunakaan aplikasi TikTok sebagai memenuhi kebutuhan bisnisnya, dapat kita lihat pada kutipan wawancara sbb:

"TikTok platform video yang mempermudah circle bisnis online jadi punya konten dan brand awareness yang baru dan juga punya out of the box dari bisnisnya" "Adanya tiktok bisa buat sesuatu yang baru dan ngejaring banyak insight dan awareness ke orang orang baru."

"Dari TikTok ngejangkau banyak banget orang."

Makna penggunaan aplikasi TikTok bagi usaha online Marica Farms yaitu sebagai platform video yang mempermudah usaha online jadi memiliki hal yang out of the box, menjangkau pasar yang luas dan membantu dalam meningkatkan pengetahuan serta awareness pada usaha online Marica Farms.

\section{Khalayak pada TikTok Marica Farms}

Pemilik usaha Marica Farms menyebutkan siapa saja khalayak pada usahanya ini.

"Yang dituju tentunya orang orang yang tertarik, ada juga artis artis selain itu juga kita menuju orang orang yang udah langganan di 
tempat lain untuk nengok marica farms"

"Bapak-bapak yang serius mau langsung visit ke kandang, ada juga remaja yang cuma nanya-nanya aja, bahkan anak anak kecil yang cuma sekedar komentar"

Khalayak pada TikTok Marica Farms yaitu orang-orang yang tertarik membeli hewan kurban, artis-artis, pelanggan dari kompetitor, hingga orangorang yang sekedar suka dengan kontenkonten TikTok Marica Farms.

\section{Kesesuaian isi pesan konten TikTok Marica Farms dengan kebutuhan khalayaknya}

Setelah pemilik usaha mengetahui siapa saja khalayak mereka, pemilik usaha dapat mengemas pesan atau konten sesuai dengan kebutuhan khalayaknya sehingga pemilik usaha dapat memenuhi kebutuhan berupa informasi kepada khalayaknya. Hal ini dapat kita lihat pada kutipan wawancara sbb:

"Konten kita harus sesuai dengan kemauan pelanggan, ngasih tau apa aja kelebihan dibandingkan dengan penjual lainnya"

"Cari tau apa aja yang sekiranya interaksinya banyak, misalnya ada konten konten yang menghibur dan selalu selipin kata kata untuk ajak mereka ke marketplace kita. Hastaghastag juga berpengaruh untuk bisa dilihat lebih banyak orang."

"Kualitas hewan hewan kurban juga ada konten konten menghibur, dan informasi seperti hewan yang bagus bagaimana."

"Isi konten kita sesuai dengan kebutuhan orang orang, mereka butuh hiburan kita sediain, apa kelebihan kita dibanding di penjual lainnya kita sediain, kita kasih tau kita topseller, gratis ongkir, dan itu semua udah sesuai kebutuhan"

Konten TikTok Marica Farms disesuaikan dengan kebutuhan khalayaknya, yaitu konten-konten mengenai kualitas hewan kurban, berbagai informasi penting tentang hewan kurban, promosi gratis ongkir, topseller, hingga konten-konten menghibur yang dapat meningkatkan interaksi dengan calon pelanggan.

\section{Respon dan kepuasan khalayak terhadap konten-konten TikTok Marica Farms}

Pemilik usaha mendapatkan timbal balik yang baik dari para khalayaknya karena mereka sudah dapat memenuhi kebutuhan informasi. Hal ini dapat dilihat dari kutipan wawancara sbb:

"Responnya mereka positif sekali, mereka selalu komentar"

"Mereka udah percaya sama kita"

"Mereka puas sama konten konten yang udah kita bikin, kita ngeliat dari followers kita yang naik terus, komentarnya juga banyak terus."

Khalayak pada TikTok Marica Farms memberikan respon yang positif dengan selalu berkomentar, sudah percaya dengan Marica Farms dan puas dengan konten-konten yang ada pada TikTok Marica Farms terlihat dari jumlah followers, likes, dan komentar yang terus meningkat.

Berdasarkan penelitian yang telah dilakukan melalui pendekatan fenomenologi maka, dengan adanya fenomena aplikasi TikTok bagi usaha online membentuk makna aplikasi TikTok sebagai medium bagi usaha online yang mempermudah dalam menjangkau pasar yang luas, memiliki konten yang out of the box serta meningkatkan pengetahuan dan kesadaran terhadap usaha online. Bagi Marica Farms sendiri, TikTok dianggap media yang paling powerful dibanding media yang lainnya, karena mampu membawa khalayak di TikTok ke akun Instagram dan marketplace yang dimilikinya. Serta dengan adanya fiturfitur yang disediakan oleh TikTok akan menambah ketertarikan khalayak dengan informasi atau konten yang mereka buat.

Selain itu, berdasarkan teori U\&G yang dijelaskan pada bab sebelumnya terdapat prinsip know your audience ketika proses komunikasi terjadi. Peneliti menganalisis berdasarkan hasil wawancara 
dengan pemilik usaha online, bahwa pelaku usaha online telah terlebih dahulu mengenal khalayaknya seperti "Siapa khalayak kita? Bagaimana karakteristiknya? Dan informasi apa yang mereka butuhkan?" dengan begitu pemilik usaha online Marica Farms dapat mengemas pesan sesuai dengan kebutuhan khalayaknya.

Sesuai dengan teori yang digunakan pada penelitian ini yaitu teori $U \& G$, maka dengan adanya penggunaan aplikasi TikTok dapat memenuhi kebutuhan pelaku usaha online Marica Farms dalam mengemas pesan pemasarannya, dan bagi khalayaknya sendiri juga dapat memenuhi kebutuhannya untuk mencari informasi mengenai hewan kurban yang dipasarkan oleh Marica Farms, hingga kebutuhan hiburan semata dari konten-konten pada TikTok Marica Farms. Dengan memenuhi kebutuhan informasi dan hiburan tersebut, maka khalayak dapat merasakan kepuasan.

\section{Kesimpulan}

Fenomenologi aplikasi TikTok bagi usaha online Marica Farms sebagai media baru untuk mempermudah usaha online jadi memiliki hal yang out of the box, menjangkau pasar yang luas dan membantu dalam meningkatkan pengetahuan serta awareness pada usaha online Marica Farms serta memenuhi kebutuhan dalam hal berbisnis karena dianggap lebih powerful dibandingkan dengan media sosial lainnya. Namun untuk menarik khalayak agar mendapatkan atensi yang banyak di TikTok diperlukan prinsip know your audience agar pelaku usaha mengetahui bagaimana seharusnya mengemas suatu pesan agar informasi tersebut dapat memenuhi kebutuhan khalayak dan memberikan kepuasan terhadap mereka.

\section{Referensi}

Effendy, Onong Ucjana. 2003. Ilmu, Teori Dan Filsafat Komunikasi. Bandung: PT Citra Aditya Bakti.

Hasbiansyah, O. 2008. "Pendekatan Fenomenologi: Pengantar Praktik Penelitian dalam Ilmu Sosial dan
Komunikasi." Mediator: Jurnal Komunikasi 9(1):163-80. doi: 10.29313/mediator.v9i1.1146.

Ikhsan, M. 2020. "Survei: 5 Media Sosial Paling Populer di Dunia." teknologi. Retrieved July 17, 2021 (https://www.cnnindonesia.com/tekn ologi/20200819154002-185-

537377/survei-5-media-sosial-palingpopuler-di-dunia).

Kriyantono, Rachmat. 2014. Teori Public Relations Perspektif Barat \& Lokal: Aplikasi Penelitian Dan Praktik. Kencana Prenada Media Group.

Kuper, Adam, Jessica Kuper, and Haris Munandar. 2000. Ensiklopedi IlmuIlmu Sosial. Edisi 2. Jakarta: Raja Grafindo Persada.

Littlejohn, Stephen W. 2002. Theories of Human Communication. 7th ed. Wadsworth/Thomson Learning.

Littlejohn, Stephen W., and Karen A. Foss. 2005. Theories of Human Communication. 8th Edition. Wadsworth, Inc.

Massie, Adesya. 2020. Kehadiran TikTok Di Masa Pandemi (The Presence of TikTok in the Pandemic). SSRN Scholarly Paper. ID 3633854. Rochester, NY: Social Science Research Network.

Mohsin, Maryam. 2021. "10 TikTok Statistics You Need to Know in 2021 [March Data]." Retrieved July 17, 2021

(https://www.oberlo.com/blog/tiktokstatistics).

Omar, Bahiyah, and Wang Dequan. 2020. "Watch, Share or Create: The Influence of Personality Traits and User Motivation on TikTok Mobile Video Usage." International Journal of Interactive Mobile Technologies (IJIM) 14(04):121-37.

Pertiwi, Wahyunanda K. 2020. "Indonesia Sumbang Angka Unduhan TikTok Terbanyak Di Dunia." Retrieved July 17 ,

2021

(https://tekno.kompas.com/read/2020/ 09/11/15010037/indonesia-sumbang- 
angka-unduhan-tiktok-terbanyak-didunia).

Stephanie, Conney. 2020. "Jumlah Pengguna Aktif Bulanan TikTok

Terungkap Halaman All

Kompas.Com." Retrieved July 17, 2021

(https://tekno.kompas.com/read/2021/ 04/19/14020037/jumlah-penggunaaktif-bulanan-tiktokterungkap?page $=$ all).

Subadi, Tjipto. 2006. "Penelitian Kualitatif." Surakarta: Muhammadiyah University Press Universitas Muhammadiyah Surakarta.

Usman, Husaini, and Purnomo Setiady Akbar. 2006. Metodologi Penelitian Sosial. Jakarta: Bumi Aksara. 